\title{
Leipzig 2005
}

\author{
By Ron Holloway
}

Fall 2005 Issue of KINEMA

\section{LEIPZIG INTERNATIONAL FESTIVAL FOR DOCUMENTARY AND ANIMATION FILMS 2005}

Counting the years since its founding in 1955, the Leipzig DOK festival should be celebrating its $50^{\text {th }}$ anniversary this year. But since two "DOK Weeks" were skipped in the 1950s by GDR festival officials for one reason or another, the big celebration is yet to come in 2007. No matter - it's the continuity that counts. Indeed, over the years, DOK Leipzig has been the best festival barometer on the calendar for charting the shifting changes in the relationship between East and West, between Eastern and Western Europe, between the German Democratic Republic and the Federal Republic of Germany.

This year, for the $48^{\text {th }}$ Leipzig International Festival for Documentary and Animation Films (3-9 October 2005), the second under the aegis of Claas Danielsen, it was no different. "Traditionally we have focused on the East," he penned in the forward of a thick 290-page catalogue. "This is also reflected in this year's program." He cited in particular the retrospective tributes to two countries in the East: "Of Megacities, Monks and Work - China Changing" and "A Short History of Polish Animated Film." These retros, in addition to some "outstanding Central and Eastern European documentary and animated films in the competitions and the international programs." Not to mention, of course, that the motif on the front cover of this year's catalogue saluted a 2004 Silver Dove winner from the Far East: Hosup Lee's And Thereafter (USA-South Korea), a penetrating psychogram about a South Korean war bride, who had married an American GI shortly after the Korean conflict and can only look back today on a scarred family history.

Three monumental documentaries were the highlights of the $48^{\text {th }}$ DOK festival: Christian Frey's The Great Buddhas (Switzerland), Michael Glawogger's Workingman's Death (Austria-Germany), and Philipp Gröning's Die Grosse Stille (The Great Silence, Germany), all running in competition and all equally deserving of the Golden Dove.

Christian Frey's The Great Buddhas (Switzerland), awarded a Silver Dove in the Long Documentary section, begins with a documentation (shot for the most part with hidden cameras) of the destruction of the great Buddhas in Afghanistan, two statues hewn into the face of a cliff in the Bamiyan valley more than 1500 years ago. Viewed up close, one is overwhelmed by the size of the Buddha - so large, in fact, that initial attempts by inexperienced Taliban religious fanatics to dynamite the statue failed completely. In the end, they had to be assisted in their act of barbarism by more experienced Saudi and Pakistani engineers. Today, Swiss scientists are exploring ways to reconstruct this World Cultural Heritage.

Even more fascinating is the decision by the director to accompany a Strasbourg professor on his search to find a third Buddha, one said to be buried underground and believed to be 300 metres long in a reclining position. An engrossing and questioning documentary, The Great Buddhas shows the callous approach by the media to the sensational side of the news while overlooking the plight of Islamic peoples around the globe who lamented this philistine act. Programmed on opening night, The Great Buddhas was a recurring attraction throughout the festival - not surprising when one considers that among the contributors to the film's musical score were Philip Glass and Arvo Pärt.

The second great event at Leipzig was Michael Glawogger's Workingman's Death (Austria-Germany), awarded the FIPRESCI Prize. Nine years in the making, and shot in five corners of the globe, Workingman's Death was hailed as a creative tour-de-force on the plight of the working man in the $21^{\text {st }}$ century. Running at two hours, and not easy viewing by any means, the documentary opens with a chronicle of survival in the Ukrainian Donbass. To make ends meet and hold them over cold winters, a group of unemployed miners re-light their lamps and go back into an abandoned mine to scratch out coal to heat their homes and keep the stoves burning. Cameraman Wolfgang Thaler braves the danger of the shaft collapsing along with the miners. The same is true when, in Indonesia, they accompany workers as they 
lug baskets of brimstone on bare backs from a fiery pit up a steep hill to sell on the market. Along the way they pass gaping tourists whose interest is an exotic photo to take home.

In Nigeria Glawogger and Thaler visit a slaughter-house on an open square splattered with mud-slime and the blood of goats and cattle. The work requires the input of children as well. In Pakistan they film workers dismantling huge rust-covered oil-takers - "the most dangerous venture in the production," said Glawogger in an interview. And in China they get as close to the furnace of a steel-mill as shooting would allow. The ironic coda to this controversial, eye-opening documentary - about men, women, and children working under intolerable conditions well nigh unimaginable in our present age - is a pleasant visit to Duisburg, where an industrial museum has been opened to illustrate working conditions in the past century. Workingman's Death, with its overpowering images and blunt outcry against the exploitation of the working man, was by far the most important film in an exemplary Leipzig program.

The third major attraction at the DOKfestival was Philipp Gröning's Die Grosse Stille (The Great Silence, Germany). According to Gröning, he waited 14 years to receive permission to film inside the Grande Charthreuse, the famous monastery at Grenoble that's also known for a liqueur distilled by lay brothers associated with the monks. Founded by St. Bruno in 1084 in the valley of Chartreuse, the Carthusians were leaders in the monastic-reform movement of the $11^{\text {th }}$ and $12^{\text {th }}$ centuries. Within the walls of their monastery, they live the solitary life of hermits in individual cells, where they pray and work, leaving only to join in communal services in the chapel and the refectory. On Sundays they eat together, and once a week they take walks for a period of conversation.

For Philipp Gröning - as producer, director, cameraman, screenwriter, and editor - to receive permission to film inside the monastery is an achievement in itself. That he was able to make a film that thrives on silence for the greater part of 164 minutes singles him out as a remarkable individual with a singular gift for sharing trust and confidence. For The Great Silence is just what it purports to be: the pulse-taking of a religious order that has existed without noticeable change or necessary reform for nearly a thousand years.

Two moments stand out on the communicative side. The first shows the monks in summer walking to an alcove, where one asks another when he will be leaving for Seoul - to found a monastery in Korea, it turns out. The other shows the monks in winter as they walk up a snow-covered hillside, then slide down on their sandals like children - a way of praising God for the very beauty of nature. The Great Silence, in which the countenances of the monks play a central role, is the kind of film that can be seen over and over again. Perhaps one has to be an advocate of "silent cinema" - the ascetic-aestheic side of Carl T. Dreyer, Robert Bresson, and Andrei Tarkovsky - to feel that a two-and-a-half-hour screening sometimes seems far too short.

Of course, the $48^{\text {th }}$ DOKfestival had other moments to remember as well. Two Finnish films were standouts. Erkko Lyytinen's Kainuun tähti ( The North Star), an insightful and humorous docu-drama about the struggle of a town council in northern Finland to keep the Vuolijoki train-wagon factory open against competition from a Spanish competitor in the European Union, well deserved the "Talent Dove" Award. Anastasia Lapsui and Markku Lehmuskallo's Fata Morgana matches archival footage with documentary elements and puppet-animation to reach beyond an ethnographic film in portraying the travail of the Chukchi people living in the far northeast of Siberia, when under the Soviet power they were taken from their natural habitat on the Arctic and Bering coasts and introduced to a questionable re-education that robbed of their language and heritage.

The Golden Dove for Long Documentary was awarded to Arunas Matelis's Pries parskrendant I zeme (Before Flying Back to Earth, Lithuania-Germany), a heart-rendering portrait of children in a cancer ward awaiting bone-marrow transplants, supported by caring parents and hospital staff. The Silver Dove for Short Document and the Ecumenical Prize was awarded to Claudio Zulian's L'Avenir ( The Future, Spain), a stylistically inventive black-and-white camera treatise about a factory town that has fallen on hard days, the twist being that the camera moves backwards through living rooms and cafes and streets as people talk about the old days as though the "future" is now the present standstill. By contrast, Gauhar Sydykova and Furkat Tursunov's straight-forward Okno (Window, Kirgizstan) comes across as a poignant short documentary sketch without dialogue about a young boy working a man's job to take care of his bed-ridden mother.

The German Documentary Competition, now in its second year as an integral part of the DOKfestival, drew 
a standing-room-only crowd for Volker Koepp's Schattenland - Reise nach Masuren (Land of Shadows Journey to Masuria), the third film in a trilogy of corners in northeastern Europe that began a decade ago with Kalte Heimat (Cold Homeland, 1995), shot in the Russian enclave around the former Prussian capital of Königsberg (Kaliningrad), and continued on with Kurische Nehrung (Curonian Spit, 2000), a portrait of a sandy beach area on the Baltic Sea coast linking the present-day Russian enclave with Poland. A master of the personal travelogue, Koepp has a knack of getting people of all backgrounds and professions to talk before Thomas Plenert's minutely observant camera. Another major plus in the films is the natural beauty of the landscape in Polish Masuria as the seasons change.

The Discovery Channel Film Prize for Best German Documentary went to Judith Keil and Antje Kruska's Dancing with Myself, a portrait of three Berlin loners of different ages and backgrounds who only feel secure when they are on the dance floor. Although the day brings little to their lives, the night by contrast offers opportunities to "dance with themselves" in a self-created vicarious environment. To the directors' credit, this psychogram doesn't put its subjects down. Rather, we feel their at-ease comfort in belonging to a crowd without joining-in. Dancing with Myself was also awarded by the Leipzig Youth Jury.

The Golden Dove for Best Animation was awarded to a film that effectively linked animation techniques with documentary shots and experimental practices. In Arash T. Riahi's Mississippi (Austria), blotches and smears on a screen to a thumping sound gradually give way to reveal at the end the churning wheel of a Mississippi River Boat. And the Audience Award went to Riho Unt's hilarious spoof of art history in Vennad karusüdamed (Brothers Bearhearts, Estonia), a 20-minute puppet animation in which three mock Russian bear-artists end up in Paris during the Belle Epoque.

More highlights at next Leipzig? There was the "Homage to Albert Maysles" that honoured one of the pioneers of the American "Direct Cinema" movement with a workshop that features some of his legendary classics shot together with his brother David: Psychiatry in Russia (1955), Salesman (1968), Grey Gardens (1976), Christo in Paris (1990), and The Legacy in Cotton (2001). AG Dok celebrated its 25th anniversary at Leipzig with a roundtable that reviewed the days and controversies since its founding in Duisburg and a closing night party sponsored by a revitalized membership. For the fifth year in a row, the "Shockin' Local Short Night Shuffle" drew an overflow crowd for an all-night screening of 67 submitted short films by local directorial talent from Saxony, Saxony-Anhalt, and Thuringia.

Last, but not least, there was the warming farewell on closing night to Otto Adler, the highly respected curator for the animation programs over the past 13 years. Indeed, without the animation section, Leipzig in the past decade would have been a festival limping along on one leg.

\section{References}

\section{AWARDS}

Golden Dove, Long Documentary: Pries parskrendant I zeme (Before Flying Back to Earth, LithuaniaGermany), dir Arunas Matelis

Silver Dove, Long Documentary: The Giant Buddhas (Switzerland), dir Christian Frei

Golden Dove, Short Documentary: Po cud (For a Miracle, Poland), dir Jarek Sztandera

Silver Dove, Short Documentary: L'Avenir (The Future) (Spain), dir Claudio Zulian

Talent Dove - Sparkasse Leipzig Prize: Kainuun tähti (The North Star, Finland), dir Erkko Lyytinen

Kinowelt DVD Award: Abel Raises Cain (USA), dir Jenny Abel

Special Mention: Okno (Window, Kyrgyzstan), dir Gauhar Sydykova, Furkat Tursunov

\section{GERMAN COMPETITION}

Discovery Channel Film Prize: Dancing with Myself (Germany), dir Judith Keil, Antje Kruska

CinemaNet Europe Award: Zur falschen Zeit am falschen Ort (Wrong Time, Wrong Place, Germany), dir Tamara Milosevic 


\section{INTERNATIONAL ANIMATION COMPETITION}

Golden Dove: Mississippi (Austria), dir Arash T. Riahi

Silver Dove: Jam Session (Poland-Germany), dir Izabela Plucinska

Special Mentions: Vennad karusüdamed (Brothers Bearhearts, Estonia), dir Riho Unt, City Paradise (UK), dir Gaelle Denis, The Man of the Hour (Taiwan), dir Kang-Wei Chen.

\section{OTHER AWARDS}

MDR (Mitteldeutscher Rundfunk) Film Prize for Eastern European Film: Zdroj (Source, Czech Republic), dir Martin Mareček

DEFA Grant Prize: Ende einer Reise - von Drahtbindern und Mausefallenhändlern (End of a JourneyThe Last Slovak Tinkers, Germany), dir Babette Ellen Kottkam

ver.di (Media Trade Union) Prize: Land Mines- A Love Story (Australia), dir Dennis O'Rourke

FIPRESCI (International Critics) Prize: Workingman's Death (Austria-Germany), dir Michael Glawogger

Ecumenical Jury: L'Avenir (The Future, Spain), dir Claudio Zulian

Leipzig Youth Jury Prize: Dancing with Myself (Germany), dir Judith Keil, Antje Kruska

Mephisto-97.6 Audience Prize: Vennad karusüdamed (Brothers Bearhearts, Estonia), dir Riho Unt.

\section{Author Information}

Ron HOLLOWAY (1933-2009) was an American critic, film historian, filmmaker and correspondent who adopted Europe as his home in the early fifties and spent much of his life in Berlin. He was an expert on the study of German cinema and against all odds produced, with his wife Dorothea, the journal German Film, keeping us up-to-date with the work of directors, producers and writers and the showing of German films around the world.

In 2007, Ron Holloway and his wife were awarded the Berlinale Camera Award. Ron also received the Bundesverdienstkreuz (German Cross of Merit), Polish Rings, Cannes Gold Medaille, the American Cinema Foundation Award, the Diploma for Support of Russian Cinema and an honorary award from the German Film Critics' Association.

Ron was also a valued contributor to Kinema for the past fifteen years. 